\title{
PDCA Cycle - Tool for Improvement of the Business Processes - Case Study
}

\author{
Peter Malega ${ }^{1}$, Naqib Daneshjo ${ }^{2}$, Vladimír Rudy ${ }^{1}$, Peter Drábik ${ }^{2}$ \\ ${ }^{1}$ Technical university in Kosice, Faculty of Mechanical Engineering, Letná 9, 04001 Košice, Slovak Republic \\ ${ }^{2}$ Faculty of Commerce of the University of Economics in BratislavaUniversity, Dolnozemská cesta 1, 85235 \\ Bratislava 5, Slovak Republic
}

\begin{abstract}
The goal of this paper is to find suitable solutions for process optimization using PDCA methodology and quality management tools. It was realized in the company that is oriented on the assembly of key sets, locks and handles. It analyzes chosen assembly processes, their critical points and identifies root causes of problems that might occur during assembly. For this purpose, different quality methods and tools are used. In this paper there are also defined the corrective actions to avoid recurrence of identified problems, implementation of these actions in production process and its standardization.
\end{abstract}

Keywords - PDCA cycle, assembly process, optimization, 5x Why, LLC.

\section{Introduction}

As the demand for the production of components for the automotive industry is in Slovak republic still very high, it is necessary to deal with it on the daily basis. With ever increasing requirements for product quality, the usage of quality tools is an essential part of the production process, especially for its systematic nature [1], [4], [8].

DOI: $10.18421 /$ TEM103-42

https://doi.org/10.18421/TEM103-42

Corresponding author: Daneshjo Naqib,

University of Economics in Bratislava Faculty of

Commerce, Slovak Republic.

Email: daneshj047@gmail.com

Received: 09 June 2021.

Revised: 21 July 2021.

Accepted: 28 July 2021.

Published: 27 August 2021.

(c) BY-NC-ND (C) 2021 Daneshjo Naqib et al; published by UIKTEN. This work is licensed under the Creative Commons Attribution-NonCommercial-NoDerivs 4.0 License.

The article is published with Open Access at www.temjournal.com
The global goal of automotive companies is to produce fast, timely and with high quality [7], [12]. Individual processes are therefore already designed based on a risk analysis. This analysis can largely eliminate the possibility of problems, so it is a set of preventive measures. However, it is not possible to design an ideal process, which implies the necessity to apply individual quality tools for continuous improvement [9], [13], [17]. Optimization of processes, i.e., production, logistics or support, is therefore necessary.

\section{Assembly Processes in the Company and the Selection of the Process for Optimization}

We have chosen three assembly processes for analysis and subsequent optimization. These processes are realized in the automotive industry company, which is located in Kosice. It is a Japanese company, which produces three product families: handles, locks and key sets. The selected processes are partial assembly operations which produce different types of locks. In Table 1. are summarized selected assembly processes [3]. 
Table 1. Summarization of selected assembly processes

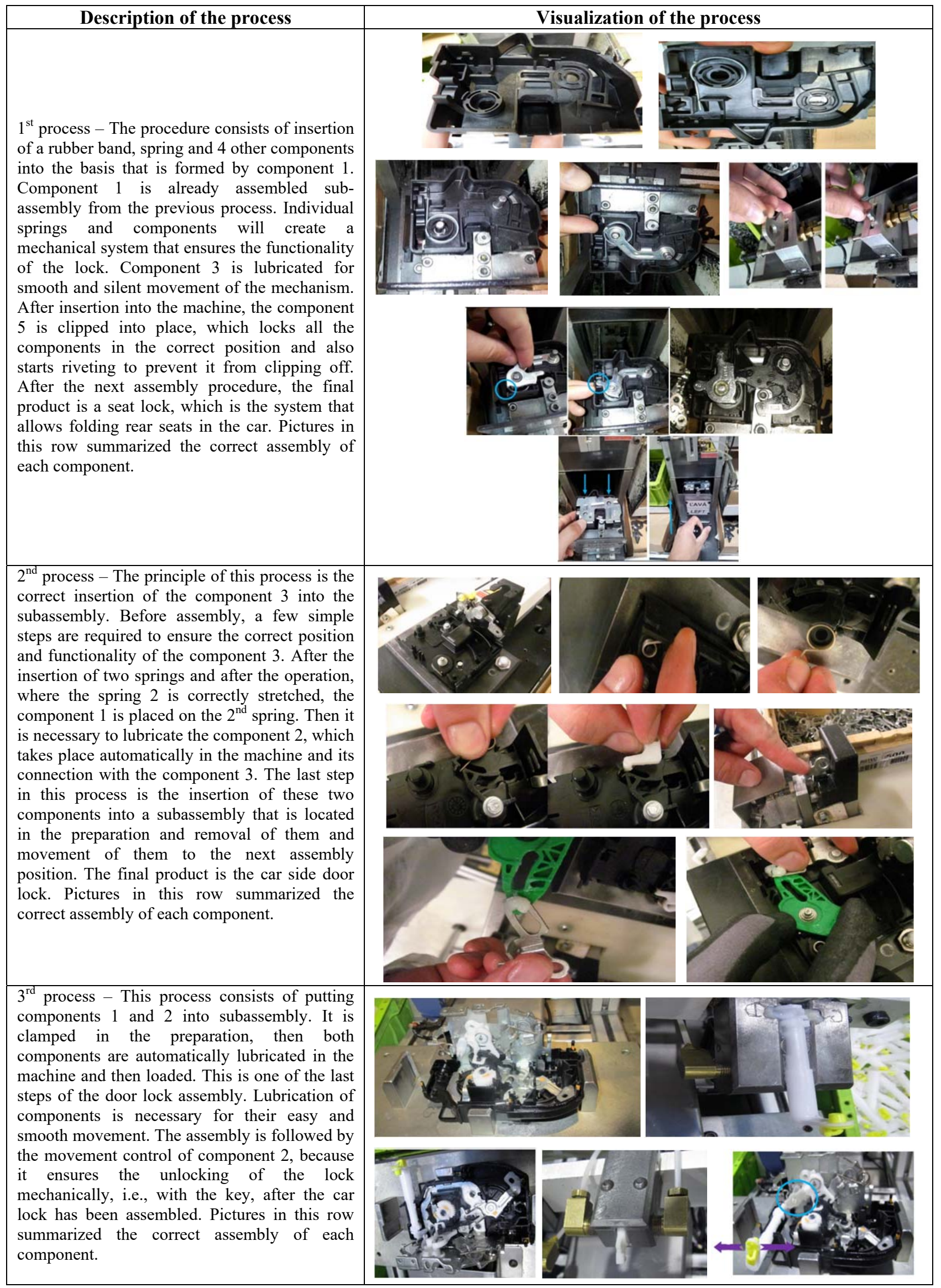




\section{Selection Process for Optimization}

Each of the processes described in Table 1. can be optimized. For the selection of the one of these processes can be used different criteria and insights, based on the fact what is expected from the optimization [2], [6]. It enables to improve the process duration, the number of produced pieces, the ergonomics of the worker, reduce the number of defects and thus the costs of poor quality, or improve the quality of the produced product. Above mentioned three processes in terms of ergonomics are very similar. The worker performs them in a standing position, manipulates with small components, which he physically puts into another component. The height of the work table is the same as the basis on which the worker stands during assembly process [5], [11]. All necessary components are located in achievable distance and are arranged in the order in which the worker puts them into another component. In principle, therefore, we do not see the ergonomic risk associated with any of these processes.

In terms of the process duration, their comparison is not objective. Each process is only a partial operation of the assembly process of different products. They are therefore produced on different production lines. The duration of one of the partial operations is adapted to the operation of the line and thus the entire product assembly is divided evenly between the individual partial operations [10]. Therefore, if we assume that each operation on the production line is performed by one operator, its operation is smooth and they all work at the same cycle time. This maximizes labour utilization and eliminates product waiting time from previous assembly operation. We can objectively compare the processes from the point of view of reduction of the number of defects and the costs of poor quality [16]. However, it is necessary to take into account the costs of poor quality as a percentage of the profit that the company receives from the process. In the last year, process 1 has the lowest costs of poor quality, only $3.7 \%$. Processes 2 and process 3 are approximately at the same level, about $11 \%$ and thus have great potential for optimization. If we wanted to compare them only in terms of the costs of poor quality, process 2 would be the worst, because in percentage it is $11 \%$ as well as process 3 , but because the price of the produced product is higher, the costs of poor quality are therefore higher [14].

Increasing the product quality can be achieved mainly by major changes in the process and thus by its modification. At the time of reviewing these processes, no modification was planned [15], [18]. The customer complained about product quality of process 3 and a customer complaint was received. Priority process for optimization has become therefore process 3 , because this process produces poor quality products, i.e., those that do not meet customer requirements.

\section{Optimization of Selected Process Using the PDCA Method}

The introduction of temporary actions and the search for the root causes of the problem in terms of the PDCA cycle are part of the phases "Plan" and "Do".

\section{A. Step of optimization procedure}

The first step in the optimization procedure in the selected company is the "Quick response", which is no more than 24 hours.

After receiving a customer complaint, a multidisciplinary team was created internally. Primarily, a quality engineer deals with the complaint, but with the assistance of engineers from other departments, such as process, maintenance, logistics, etc. The first step based on information from the customer was to determine which of the production processes caused the error, when it happened, and also to ensure sorting of the produced pieces internally and at the customer. The purpose of internal sorting is to send a secure delivery as soon as possible to finish sorting at the customer. The processing of customer notification data was as follows:

- Problem description - the key does not return to its original position. Customer notification showed the problem as in Figure 1.

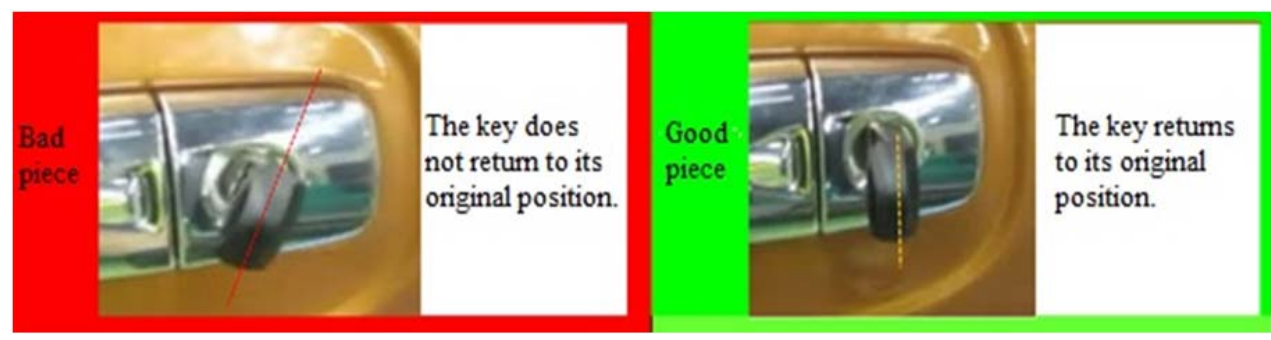

Figure 1. Bad piece (scrap) vs. good piece 
- What is the problem - description of the problem using method "7x Why" was processed in Table 2.

Table 2. Customer's view of the problem

\begin{tabular}{|c|c|}
\hline \multicolumn{2}{|c|}{ Customer's view } \\
\hline What has happened? & $\begin{array}{c}\text { The key does not return to } \\
\text { its original position. }\end{array}$ \\
\hline Why is this a problem? & $\begin{array}{c}\text { It cannot be pulled out of } \\
\text { the lock. }\end{array}$ \\
\hline When did it happen? & 14.2. \\
\hline Where did it happen? & On the assembly line \\
\hline Who found out? & Operator \\
\hline How did he find out? & Manual \\
\hline How many pieces? & 5 \\
\hline
\end{tabular}

Based on photos of the scrap from the customer, it was identified when this scrap was made. On the records from the production line were checked if there were any problems in the process, slowing down or stopping the production line, or training new operators. The result was that no unusual circumstances were found, the scrap was made in a standard process. Based on previous experience, it was possible to identify the problematic area, i.e., the place that caused the defect (red arrow in Figure 2.). The fact that the key was not rotating and did not return to its original position was caused by the LCE component, i.e., component 1 , which has been assembled into a subassembly, as it was described above in process 3 . The component of subassembly that can affect LCE movement is black component, which consists of putting in the LCE, because they have more contact areas. For the purpose of further analysis, it will be called as BTR.

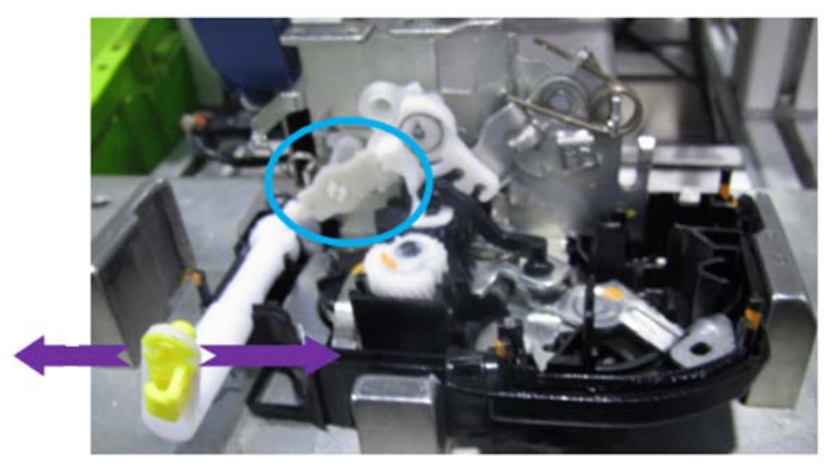

Figure 2. Error detection in process

After processing all available data and identification of the scrap in the process, which are summarized in Table 3., it was necessary to introduce temporary measures to ensure that potentially bad pieces are not sent to the customer. The corrective actions at the supplier are shown in Table 4. and corrective actions at the customer are shown in Table 5. The company also proceeded to sort the already produced stock, because of the necessity to send secured delivery as soon as possible and to ensure the continuity of the production process at the customer.

The sorting instructions are summarized in Table 6. The next step was to inform all production workers about the problem. The last temporary measure was to add lubrication of the affected part of the lock manually outside the production line. Such a temporary measure has to be always applied until the problem will be resolved, i.e., the cause of the problem will be identified and corrective measures will be successfully implemented.

Table 3. Internal view of the problem

\begin{tabular}{|c|c|}
\hline \multicolumn{2}{|c|}{ Supplier's view } \\
\hline $\begin{array}{c}\text { Difference between good } \\
\text { and bad? }\end{array}$ & $\begin{array}{c}\text { A good piece - LCE } \\
\text { movement is smooth } \\
\text { Scrap - LCE movement is } \\
\text { difficult and LCE is stuck }\end{array}$ \\
\hline $\begin{array}{c}\text { Were the pieces made in } \\
\text { a standard process? }\end{array}$ & Yes \\
\hline $\begin{array}{c}\text { When were the pieces } \\
\text { produced? }\end{array}$ & $\begin{array}{c}\text { 17.1., According to } \\
\text { engraving on the piece }\end{array}$ \\
\hline $\begin{array}{c}\text { Who made the pieces? } \\
\text { In what other processes } \\
\text { is the product used? }\end{array}$ & $\begin{array}{c}\text { Operator, Working shift C, } \\
\text { Final production line }\end{array}$ \\
\hline $\begin{array}{c}\text { Catch the company the } \\
\text { scrap when it returns to } \\
\text { the standard process? }\end{array}$ & None \\
\hline $\begin{array}{c}\text { Has the problem } \\
\text { occurred in the past } \\
\text { internally or at the } \\
\text { customer? }\end{array}$ & No \\
\hline
\end{tabular}

Table 4. Immediate corrective actions at supplier

\begin{tabular}{|c|c|c|c|}
\hline $\begin{array}{c}\text { At supplier } \\
\text { (internally) }\end{array}$ & Who & When & Where \\
\hline $\begin{array}{c}\text { Sorting of finished } \\
\text { products }\end{array}$ & $\begin{array}{c}\text { Quality } \\
\text { Technician }\end{array}$ & 14.2. & Warehouse \\
\hline $\begin{array}{c}\text { Information about } \\
\text { complaints into } \\
\text { production - } \\
\text { retraining of } \\
\text { operators }\end{array}$ & $\begin{array}{c}\text { Quality } \\
\text { Engineer }\end{array}$ & 14.2. & Production \\
\hline $\begin{array}{c}\text { Temporary } \\
\text { instruction - } \\
\text { addition of } \\
\text { lubrication on the } \\
\text { production line }\end{array}$ & $\begin{array}{c}\text { Quality } \\
\text { Engineer }\end{array}$ & 15.2. & Production \\
\hline
\end{tabular}

Table 5. Immediate corrective action at customer

\begin{tabular}{|c|c|c|c|}
\hline $\begin{array}{c}\text { At the } \\
\text { customer }\end{array}$ & Who & When & Where \\
\hline $\begin{array}{c}\text { Sending the } \\
\text { scrap }\end{array}$ & Resident & 16.2. & Customer \\
\hline $\begin{array}{c}\text { External } \\
\text { sorting }\end{array}$ & Resident & 15.2. & Customer \\
\hline
\end{tabular}


Table 6. Instruction for sorting



\section{B. Factor analysis FTA for problem formation}

The aim of FTA analysis is to identify the root cause of the problem by analyzing all $\mathrm{M}$ factors that enter or influence the process (men, machine, material, etc.). Therefore, the company gradually analyzed the individual factors, by each factor the company specified the standard, the status of the assessed factor for the good piece and scrap, and finally proceeded to evaluate whether the standard was followed, whether it is correct and whether it is the root cause.

Given the character and possible scope of the paper, we will not analyse all factors in detail, so we will show only one of the FTA analyses - concretely FTA analysis of the method is in Table 7. 
Table 7. Factor analysis - method

\begin{tabular}{|c|c|c|c|c|c|c|}
\hline Factor & Specification & Good piece & Scrap & $\begin{array}{c}\text { Is } \\
\text { standard } \\
\text { OK? }\end{array}$ & $\begin{array}{c}\text { Has the } \\
\text { standard been } \\
\text { adhered to? }\end{array}$ & $\begin{array}{c}\text { Is this a } \\
\text { root } \\
\text { cause? }\end{array}$ \\
\hline & $\begin{array}{l}\text { The subunit is } \\
\text { put in nest and } \\
\text { fixed. Without } \\
\text { lubrication, it is } \\
\text { not possible to } \\
\text { remove a } \\
\text { subunit from } \\
\text { the nest. }\end{array}$ & $\begin{array}{l}\text { The subunit is } \\
\text { put in nest and } \\
\text { fixed. Without } \\
\text { lubrication, it is } \\
\text { not possible to } \\
\text { remove a subunit } \\
\text { from the nest. }\end{array}$ & $\begin{array}{l}\text { The subunit is } \\
\text { put in nest and } \\
\text { fixed. Without } \\
\text { lubrication, it is } \\
\text { not possible to } \\
\text { remove a } \\
\text { subunit from the } \\
\text { nest. }\end{array}$ & Yes & Yes & No \\
\hline
\end{tabular}

We will list the final findings that can be summarized as follows:

- Dimensions on BTR are outside specifications.

- There is extra material on the LCE but does not affect the force required to unlock and lock it.

- There is high force to unlock and lock with key on test piece 1 .

- There is high force to unlock and lock with key when lubricant weight on LCE is below the minimum value of $0.1 \mathrm{~g}$.

- The weight of the LCE lubricant dosed automatically by the machine is not clearly defined and is not in the specification.

By evaluation of the individual factors and their combination, the company found that the test piece 1 had a sub-unit from the 5G cavity using BTR. Also, when measuring the BTR, the company found out the dimensions outside the specification on $5 \mathrm{G}$ cavity pieces. Thus, as one of the root causes, out-ofspecification dimensions were identified on sub-units using the BTR from the 5G cavity. The second root cause was the amount of lubricant below the lower tolerance limit dosed automatically by the machine. The occurrence of the defect was not $100 \%$, because it had occurred only when the BTR 5G was combined with the amount of lubricant below the lower tolerance limit.

\section{5x Why root cause analysis}

It is used for a thorough investigation of root causes and revealing reasons for their creation.

Table 8 . shows $5 x$ Why analysis for the potential cause 1 (the unknown amount of lubricant on the LCE) and Table 9. shows the analysis (the dimensions on the BTR are out of specification).

Table 8. 5x Why-first cause - the unknown amount of lubricant on the LCE

\begin{tabular}{|c|l|}
\hline Possible cause & \multicolumn{1}{|c|}{$\begin{array}{c}\text { Unknown amount of LCE } \\
\text { lubricant }\end{array}$} \\
\hline 1. Why? & $\begin{array}{l}\text { The production line has } \\
\text { automatic LCE lubrication. }\end{array}$ \\
\hline $\begin{array}{l}\text { How was it } \\
\text { confirmed? }\end{array}$ & $\begin{array}{l}\text { According to working } \\
\text { instructions. }\end{array}$ \\
\hline
\end{tabular}

\begin{tabular}{|l|l|}
\hline 2. Why? & $\begin{array}{l}\text { To keep the amount of lubricant } \\
\text { under control and to prevent the } \\
\text { LCE from being shipped to the } \\
\text { next process without lubrication. }\end{array}$ \\
\hline $\begin{array}{l}\text { How was it } \\
\text { confirmed? }\end{array}$ & $\begin{array}{l}\text { Without lubrication it is not } \\
\text { possible to remove a piece from } \\
\text { the nest. }\end{array}$ \\
\hline 3. Why? & $\begin{array}{l}\text { As this is an automatic process, } \\
\text { the amount of lubricant is no } \\
\text { longer controlled. }\end{array}$ \\
\hline $\begin{array}{l}\text { How was it } \\
\text { confirmed? }\end{array}$ & $\begin{array}{l}\text { According to control } \\
\text { instructions. }\end{array}$ \\
\hline 4. Why? & $\begin{array}{l}\text { The operator checks only the } \\
\text { presence of lubricant on the } \\
\text { LCE. }\end{array}$ \\
\hline $\begin{array}{l}\text { How was it } \\
\text { confirmed? }\end{array}$ & $\begin{array}{l}\text { According to control } \\
\text { instructions. }\end{array}$ \\
\hline 5. Why? & From past experience. \\
\hline $\begin{array}{l}\text { How was it } \\
\text { confirmed? }\end{array}$ & In the control plan. \\
\hline
\end{tabular}

Table 9. 5x Why-second cause-dimensions on the BTR are out of specification

\begin{tabular}{|l|l|}
\hline Possible cause & $\begin{array}{c}\text { Dimensions on BTR are out of } \\
\text { specification }\end{array}$ \\
\hline 1. Why? & $\begin{array}{l}\text { BTR is produced by the supplier } \\
\text { and the dimensions are not } \\
\text { checked at the initial inspection. }\end{array}$ \\
\hline $\begin{array}{l}\text { How was it } \\
\text { confirmed? }\end{array}$ & Instruction for initial control. \\
\hline 2. Why? & $\begin{array}{l}\text { Dimensions are not defined as } \\
\text { critical. }\end{array}$ \\
\hline $\begin{array}{l}\text { How was it } \\
\text { confirmed? }\end{array}$ & Drawing. \\
\hline 3. Why? & $\begin{array}{l}\text { The dimensions are not checked } \\
\text { by the supplier within the } \\
\text { inspection plan. }\end{array}$ \\
\hline $\begin{array}{l}\text { How was it } \\
\text { confirmed? }\end{array}$ & Supplier control plan. \\
\hline 4. Why? & Dimensions are based on mould. \\
\hline $\begin{array}{l}\text { How was it } \\
\text { confirmed? }\end{array}$ & 3D model of BTR and form. \\
\hline 5. Why? & $\begin{array}{l}\text { Mould dimensions are outside } \\
\text { the 5G cavity specification. }\end{array}$ \\
\hline $\begin{array}{l}\text { How was it } \\
\text { confirmed? }\end{array}$ & $\begin{array}{l}\text { Mould measurement at the } \\
\text { supplier. }\end{array}$ \\
\hline
\end{tabular}




\section{Factor analysis FTA for problem detection}

The aim of this analysis is to evaluate, why individual $\mathrm{M}$ factors did not identify the problem after its occurrence. We followed the same procedure as for FTA problem formation. In Table 10. there is a factor analysis for all factors affecting problem detection. Summary of findings are as follows:

- After assembly, the operator did not identify the LCE heavy movement, either the movement was not heavy, or the operator did not control according to control instruction.

- The final lock function test is automatic, the machine turns the LCE to the locked position and back to the unlocked position. The lock passed the test, because the machine does not measure the power to lock and unlock. LCE could be mechanically rewind, the machine did not detect that its movement is difficult.

Table 10. Factor analysis - problem detection

\begin{tabular}{|c|c|c|c|c|c|c|c|}
\hline $\mathbf{M}$ & Factor & Specification & Good piece & Scrap & $\begin{array}{c}\text { Is } \\
\text { standard } \\
\text { OK? }\end{array}$ & $\begin{array}{c}\text { Has the } \\
\text { standard } \\
\text { been } \\
\text { adhered to? }\end{array}$ & $\begin{array}{c}\text { Is this a } \\
\text { root } \\
\text { cause? }\end{array}$ \\
\hline$\sum_{\Sigma}^{\bar{E}}$ & $\begin{array}{c}\text { LCE } \\
\text { movement } \\
\text { control after } \\
\text { assembly }\end{array}$ & $\begin{array}{l}\text { The movement } \\
\text { of the LCE is } \\
\text { smooth and the } \\
\text { LCE does not } \\
\text { stall }\end{array}$ & $\begin{array}{l}\text { The movement } \\
\text { of the LCE is } \\
\text { smooth and the } \\
\text { LCE does not } \\
\text { stall }\end{array}$ & $\begin{array}{l}\text { LCE movement } \\
\text { is not smooth } \\
\text { and LCE is } \\
\text { stalling }\end{array}$ & Yes & No & Yes \\
\hline : & $\begin{array}{c}\text { Control of } \\
\text { the lock } \\
\text { functionality }\end{array}$ & $\begin{array}{c}\text { The piece passes } \\
\text { the final } \\
\text { production line } \\
\text { test }\end{array}$ & $\begin{array}{c}\text { The piece } \\
\text { passes the final } \\
\text { production line } \\
\text { test }\end{array}$ & $\begin{array}{l}\text { The piece does } \\
\text { not pass the } \\
\text { final production } \\
\text { line test }\end{array}$ & Yes & Yes & No \\
\hline 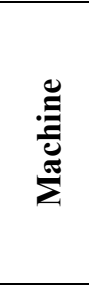 & $\begin{array}{l}\text { Control of } \\
\text { the lock } \\
\text { functionality }\end{array}$ & $\begin{array}{l}\text { In the final } \\
\text { test, the LCE } \\
\text { is rotated by } \\
\text { the machine }\end{array}$ & $\begin{array}{l}\text { The machine } \\
\text { turns the LCE } \\
\text { to the locked } \\
\text { position and } \\
\text { back to the } \\
\text { unlocked } \\
\text { position }\end{array}$ & $\begin{array}{l}\text { The machine } \\
\text { does not turn } \\
\text { the LCE to the } \\
\text { locked position } \\
\text { and back to the } \\
\text { unlocked } \\
\text { position }\end{array}$ & $?$ & Yes & $?$ \\
\hline 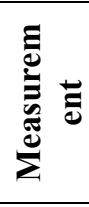 & $\begin{array}{c}\text { Measurement } \\
\text { of force to } \\
\text { lock and } \\
\text { unlock }\end{array}$ & $\begin{array}{c}\text { Force } \\
\text { measurement is } \\
\text { not a part of the } \\
\text { final lock } \\
\text { functionality test }\end{array}$ & $\begin{array}{l}\text { Unlocking } \\
\text { force is in the } \\
\text { specification }\end{array}$ & $\begin{array}{l}\text { Unlocking } \\
\text { force is out of } \\
\text { the } \\
\text { specification }\end{array}$ & $?$ & Yes & $?$ \\
\hline
\end{tabular}

\section{E. 5x Why analysis for problem detection}

In Table 11. and Table 12. there are 5x Why analyses for possible causes, because of which the problem was not detected. In Tab. 10. is human factor failure and in Table 12. is machine detection during the final test.
Table 11. 5x Why analysis - first factor - human factor failure

\begin{tabular}{|l|l|}
\hline \multicolumn{1}{|c|}{$\begin{array}{c}\text { Possible } \\
\text { cause }\end{array}$} & The operator did not detect a problem \\
\hline 1. Why? & LCE movement was not difficult. \\
\hline $\begin{array}{l}\text { How was it } \\
\text { confirmed? }\end{array}$ & Unconfirmed and unlikely. \\
\hline 2. Why? & $\begin{array}{l}\text { The operator did not make control, or did } \\
\text { the control incorrectly. }\end{array}$ \\
\hline $\begin{array}{l}\text { How was it } \\
\text { confirmed? }\end{array}$ & Unconfirmed. \\
\hline 3. Why? & $\begin{array}{l}\text { He was not familiar with the control } \\
\text { instruction. }\end{array}$ \\
\hline $\begin{array}{l}\text { How was it } \\
\text { confirmed? }\end{array}$ & $\begin{array}{c}\text { Unconfirmed - all operators on C } \\
\text { working shift are trained in work and } \\
\text { control instructions. }\end{array}$ \\
\hline 4. Why? & Operator inattention. \\
\hline $\begin{array}{l}\text { How was it } \\
\text { confirmed? }\end{array}$ & Unconfirmed, but probable. \\
\hline 5. Why? & Operator in training. \\
\hline $\begin{array}{l}\text { How was it } \\
\text { confirmed? }\end{array}$ & $\begin{array}{c}\text { Unconfirmed, unlikely - all pieces after } \\
\text { operators in training are controlled by the } \\
\text { team leader. }\end{array}$ \\
\hline
\end{tabular}


Table 12. 5x Why analysis - second factor - machine detection during the final test

\begin{tabular}{|l|l|}
\hline $\begin{array}{c}\text { Possible } \\
\text { cause }\end{array}$ & $\begin{array}{l}\text { The machine did not detect a problem } \\
\text { during the final test }\end{array}$ \\
\hline 1. Why? & $\begin{array}{l}\text { The machine tests mechanically locking } \\
\text { and unlocking with LCE. }\end{array}$ \\
\hline $\begin{array}{l}\text { How was it } \\
\text { confirmed? }\end{array}$ & Working instruction. \\
\hline 2. Why? & $\begin{array}{l}\text { Scrap can be locked and unlocked } \\
\text { mechanically. }\end{array}$ \\
\hline $\begin{array}{l}\text { How was it } \\
\text { confirmed? }\end{array}$ & Test. \\
\hline 3. Why? & The power to lock and unlock is higher. \\
\hline $\begin{array}{l}\text { How was it } \\
\text { confirmed? }\end{array}$ & Measurement. \\
\hline 4. Why? & $\begin{array}{l}\text { The machine during test does not } \\
\text { measure the amount of force required to } \\
\text { lock and unlock. }\end{array}$ \\
\hline $\begin{array}{l}\text { How was it } \\
\text { confirmed? }\end{array}$ & Control of machine functions. \\
\hline 5. Why? & $\begin{array}{l}\text { It has not been entered requirement for } \\
\text { such measurements. }\end{array}$ \\
\hline $\begin{array}{l}\text { How was it } \\
\text { confirmed? }\end{array}$ & From past experience. \\
\hline
\end{tabular}

\section{F. Proposal for improving the state of processes in the company based on the PDCA cycle}

We focused on the analysis of the selected problem. From the point of view of the PDCA cycle, these were therefore the phases "Plan" and "Do". In the chapter we will deal with the design and implementation of the solution, so we will deal with the remaining two phases - concretely "Check" and "Act".
After identification of the potential root causes, we proceeded to reproduce the defect. It is effective setting of conditions in the way so that they remind the conditions that were characteristic for the process at the time of the defect. The description of each step is in Table 13. This step belongs to the "Check" phase, so it is a verification of the root cause identification. The next step is to propose an action plan to implement the corrective actions and to verify their functionality in practice, which allows to made a decision whether another PDCA cycle has to be started.

Table 13. Reproduction of the defect

\begin{tabular}{|l|l|}
\hline $\begin{array}{l}\text { What was done to } \\
\text { reproduce the } \\
\text { defect? }\end{array}$ & $\begin{array}{l}\text { Production of finished products } \\
\text { with amount of lubricant on LCE } \\
\text { below the minimum tolerance of } \\
0.1 \mathrm{~g} \text { in combination with BTR from } \\
5 \mathrm{G} \text { cavity. }\end{array}$ \\
\hline Why was it done? & $\begin{array}{l}\text { Assumption that the root cause of } \\
\text { the problem is a small amount of } \\
\text { lubricant on LCE. }\end{array}$ \\
\hline How was it done? & $\begin{array}{l}\text { Using LCE with the amount of } \\
\text { lubricant below the lower tolerance. }\end{array}$ \\
\hline When was it done? & 20.3 . \\
\hline What was the result? & $\begin{array}{l}\text { The measured values of the force } \\
\text { required for unlocking/locking were } \\
\text { the same as for the complained } \\
\text { parts from the customer. }\end{array}$ \\
\hline $\begin{array}{l}\text { Has root cause been } \\
\text { confirmed? }\end{array}$ & \multicolumn{1}{|c}{ Yes. } \\
\hline
\end{tabular}

A separate action plan has to be created for each root cause identified. The assumption of success is also following statistical monitoring of the solved problem recurrence. A summary of all actions is in Table 14.

Table 14. Action plan for the implementation of corrective actions

\begin{tabular}{|c|c|c|c|c|c|}
\hline Root cause & Corrective actions & Expected result & $\begin{array}{c}\text { Responsible } \\
\text { person }\end{array}$ & $\begin{array}{c}\text { Planned } \\
\text { date }\end{array}$ & $\begin{array}{l}\text { Real } \\
\text { date }\end{array}$ \\
\hline $\begin{array}{l}\text { The amount of } \\
\text { lubricant on } \\
\text { LCE is } \\
\text { unknown }\end{array}$ & $\begin{array}{l}\text { Monitoring the weight of } \\
\text { lubricant applied to LCE: } \\
\text { 1. Addition of control point- } \\
\text { control of the lubricant weight } \\
\text { applied to the control } \\
\text { instruction } \\
\text { 2. Addition of lubricant quantity } \\
\text { control record } \\
\text { 3. Training of operators with } \\
\text { training record }\end{array}$ & $\begin{array}{l}\text { Amount of } \\
\text { applied lubricant } \\
\text { is under control }\end{array}$ & $\begin{array}{l}\text { Quality } \\
\text { Engineer }\end{array}$ & 1.3 . & 1.3 \\
\hline $\begin{array}{l}\text { The amount of } \\
\text { lubricant on } \\
\text { LCE is } \\
\text { unknown }\end{array}$ & $\begin{array}{l}\text { Setting the application of a } \\
\text { larger amount of lubricant on } \\
\text { LCE automatic lubricators }\end{array}$ & $\begin{array}{l}\text { Increasing the } \\
\text { amount of } \\
\text { lubricant between } \\
\text { LCE and BTR for } \\
\text { the reduction of } \\
\text { their mutual } \\
\text { resistance to the } \\
\text { movement of LCE }\end{array}$ & $\begin{array}{l}\text { Process } \\
\text { Engineer }\end{array}$ & 3.3 . & 10.3 . \\
\hline
\end{tabular}




\begin{tabular}{|c|c|c|c|c|c|}
\hline $\begin{array}{c}\text { The BTR } \\
\text { dimension is out } \\
\text { of specification }\end{array}$ & $\begin{array}{c}\text { Modification of the BTR } \\
\text { injection mould - cavity 5G }\end{array}$ & $\begin{array}{c}\text { Dimension } \\
\text { adjustment to } \\
\text { BTR - return to } \\
\text { tolerance field }\end{array}$ & $\begin{array}{c}\text { Supplier of } \\
\text { BTR }\end{array}$ & 14.3. & 20.3. \\
\hline
\end{tabular}

When implementing corrective actions, we follow the action plan:

1- Addition of control point - control of the lubricant applied weight to the control instruction.

2- Addition of lubricant quantity control record.
The basic way of knowledge usage gained from the analysis is the adjustment of standards. In the original control instruction for process 3 , there was only a visual presence control. It was therefore necessary to update it by addition of checkpoint weight control of the lubricant. The modified control instruction is in Table 15.

Table 15. Modified control instruction

\begin{tabular}{|c|c|c|c|c|}
\hline Description of the checkpoint & $\begin{array}{c}\text { Type of the } \\
\text { control }\end{array}$ & Defined standard & $\begin{array}{c}\text { Measurement } \\
\text { frequency }\end{array}$ & Actions \\
\hline $\begin{array}{c}\text { Presence of lubricant on } \\
\text { LCE after lubrication in the } \\
\text { preparation }\end{array}$ & Visually & $\begin{array}{c}\text { Visible component } \\
\text { lubrication }\end{array}$ & $100 \%$ & $\begin{array}{c}\text { Inform the team } \\
\text { leader }\end{array}$ \\
\hline $\begin{array}{c}\text { Lubricant weight control on } \\
\text { LCE }\end{array}$ & Weight & $0,3 \mathrm{~g}-1 \mathrm{~g}$ & $\begin{array}{c}\text { At the start of } \\
\text { production in } \\
\text { the registration } \\
\text { form }\end{array}$ & $\begin{array}{c}\text { Inform the team } \\
\text { leader and lubricate } \\
\text { the BTR manually } \\
\text { with a paintbrush }\end{array}$ \\
\hline Finished piece & $\begin{array}{c}\text { Visually, } \\
\text { manually }\end{array}$ & $\begin{array}{c}\text { Correct fixation of } \\
\text { components in the } \\
\text { final product has to be } \\
\text { controlled by their } \\
\text { movement }\end{array}$ & $100 \%$ & $\begin{array}{c}\text { Inform the team } \\
\text { leader }\end{array}$ \\
\hline
\end{tabular}

In addition to editing the control instruction, it was necessary to create a control record, where each operator records information about the lubricant presence, its weight, the date and time of the control, its name and the working shift. Control records serve as evidence for the customer to verify the fact that the changes have been implemented in the process and they can also help to exclude the possibility that the root cause is the same as in the past and the problem arose due to non-compliance with proper workflow.

3- Training of operators with training record - if the current version of the control instruction changes or a new form is added to the production line, all operators working on it have to be retrained.

4- Setting the application of a larger amount of lubricant on LCE automatic lubricators.
5- Mould modification for BTR injection - cavity $5 \mathrm{G}$.

\section{Monitoring the Effectiveness of Corrective Actions}

After implementation of individual corrective actions, starts the statistical verification of their effectiveness. It is possible to use the Pareto diagram, which is used to monitor the occurrence of individual defects. From the following two graphs, it is possible to see that the number of final products with the problem of LCE heavy movement was successfully eliminated, as it occurred only once in March (Figure 3.) and not once in April (Figure 4.). Since the last corrective action was taken on 20.3., the result of the Pareto analysis confirms that the problem solution was adequate and correct. The problem did not recur in the next month. 


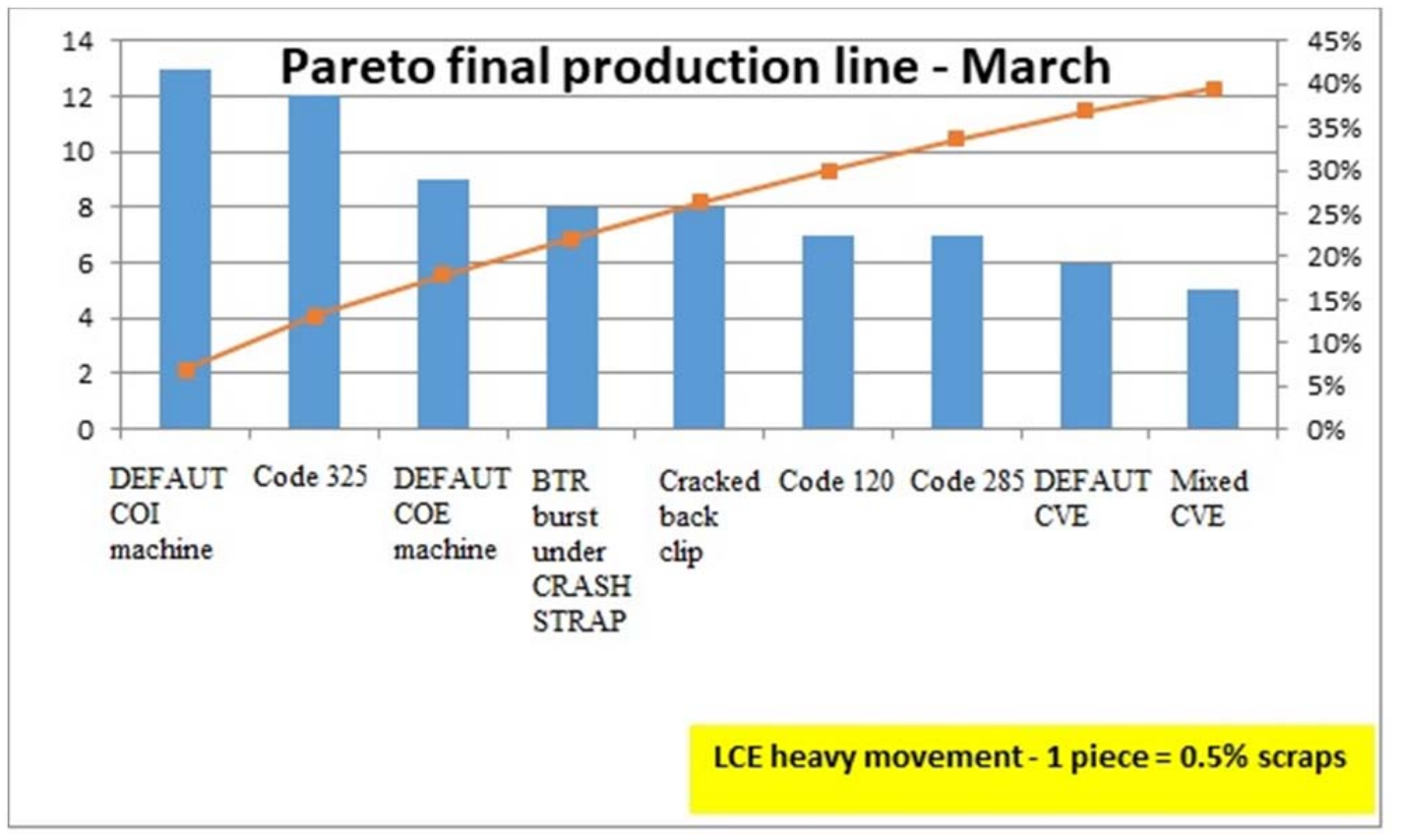

Figure 3. Pareto analysis-occurrence of defects on the final production line in March



Figure 4. Pareto analysis-occurrence of defects on the final production line in April

\section{Introduction of New Standards}

The last step in the successful implementation of corrective measures is the updating of existing standards or the introduction of new standards. In the automotive industry, where all documents used for quality management (working and control instructions, control plan, FMEA, etc.) are interconnected and it is important to update each of them separately. Table 16. provides an overview of which documents have been modified based on the analysis.
Table 16. Actualization of the documentation

\begin{tabular}{|c|c|c|c|c|}
\hline \multirow{2}{*}{ Documentation } & \multirow{2}{*}{$\mathbf{Y} / \mathbf{N}$} & \multicolumn{3}{|c|}{ Responsible Planned Realization } \\
\hline & & person & date & date \\
\hline Product FMEA & $\mathrm{N}$ & & & \\
\hline Process FMEA & $\mathrm{N}$ & & & \\
\hline $\begin{array}{c}\text { Logistics } \\
\text { FMEA }\end{array}$ & $\mathrm{N}$ & & & \\
\hline Control plan & Y & $\begin{array}{c}\text { Quality } \\
\text { Engineer }\end{array}$ & 1.3 . & 1.3 . \\
\hline $\begin{array}{l}\text { Maintenance } \\
\text { plan }\end{array}$ & $\mathrm{N}$ & & & \\
\hline Instructions & $\begin{array}{c}\mathrm{Y} \\
\text { Control } \\
\text { instruction }\end{array}$ & $\begin{array}{l}\text { Quality } \\
\text { Engineer }\end{array}$ & 1.3 . & 1.3 . \\
\hline Product design & $\mathrm{N}$ & & & \\
\hline $\begin{array}{c}\text { LLC - What } \\
\text { we have } \\
\text { learned }\end{array}$ & Á & $\begin{array}{c}\text { Quality } \\
\text { Engineer }\end{array}$ & 15.3 & 20.3 . \\
\hline
\end{tabular}


When changing a point in the control instruction, it is also necessary to make a change in the control plan. Since a checkpoint was added to the instruction, we added the same checkpoint to the control plan. Therefore, in addition to the visual control of the lubricant presence, there will also be a weight control of the lubricant in both documents, always at the beginning of the reference production with the LCE. This control will be performed by weighing the piece after lubrication and entering the measured value in the prescribed form. If the operator finds that the lubricant weight is out of specification, he immediately informs the team leader.

After concluding the analysis and application of corrective actions, the so-called LLC - Lesson learned card, i.e., a card of what we have learned about the problem is made. We distinguish two types, one for the problem occurrence and the other for the problem detection. Table 17. is LLC for problem detection and in Table 18. is the LLC for problem occurrence.

Table 17. LLC for problem detection



Another important step is to verify whether a similar process, and therefore a similar problem, is repeated also on other production lines. In this case, it is necessary to adjust the standards for all such production lines to avoid recurrence of the problem. The overview of the solution application to other production lines and products are in Table 18. 
Table 18. Application of corrective measures to similar production lines/products

\begin{tabular}{|c|c|c|}
\hline YES & Production line & $\begin{array}{c}\text { All final } \\
\text { production lines }\end{array}$ \\
\cline { 1 - 1 } X & Product & Not applicable \\
\hline
\end{tabular}

\section{Conclusion}

In this paper, we made the analysis of three assembly processes, which are used to produce different types of locks. We compared them based on different criteria. Based on the received customer complaint, we evaluated the number 3 as a critical process. We analyzed it using the PDCA method. The first step was to implement immediate corrective action to secure the customer. In the Plan and Do section, we examined the influence of all factors on the production process. Only after summarization of them we began to identify the root causes of the problem. One of the most important principles of the PDCA cycle is to analyse all potential factors before focusing on those that cause the problem. This simply eliminates the possibility of underestimating one of the factors. Then we dealt with the proposal of solutions for process optimization. From the point of view of the PDCA cycle, these are Check and Act phases. Based on the identification of the root causes of the problem, we introduced long-term corrective measures and made adjustments of individual production and control documents. We confirmed their effectiveness in the first month after implementation.

The next necessary step will be to continue in process monitoring and verification of long-term effectiveness of the corrective actions. If we will identify the problem again in the future, the PDCA cycle will begin again with phases Plan and Do, and further factor analysis, root cause identification, and finally process optimization will be required.

\section{Acknowledgement}

This work has been supported by the Scientific Grant Agency of the Ministry of Education of the Slovak Republic (Project KEGA 032EU-4/2020 and VEGA 1/0438/20)

\section{References}

[1]. Chase, R. B., Aquilano J. N. (1995). Production and operations management: Manufacturing and services. 7th ed. Chicago: Irwin. 853 s. ISBN 0-256- 14023-5.

[2]. Daneshjo, N. \& Rudy, V. \& et al. (2018). Inteligent industrial engineering - Innovation potential. San Antonio. 297 p. ISBN 978-0-578-40289-5.

[3]. Feylizadeh, M. R., \& Bagherpour, M. (2011). Application of optimization techniques in production planning context: A review and extension. International Journal of Manufacturing Systems, 1(1), 1-8.

[4]. Fletcher, R. (2000). Practical Methods of Optimization. Wiley, Dundeem. ISBN 0-471-91547-55.

[5]. Hansen, R. (2005). Overall equipment effectiveness: a powerful production/maintenance tool for increased profits. New York, Industrial Press Inc. ISBN 0-83113138-1.

[6]. Heskova, M. \& et al. (2006). Category management. Praha, Profess Consulting. ISBN 80-7259-049-0.

[7]. Hrubec, J. (2001). Quality management. Nitra: SPU, ISBN 80-7173-849-6

[8]. Kapsdorferová, Z. (2008). Manažment kvality. Nitra, Slovakia: SPU, $120 \mathrm{p}$.

[9]. Kotter, J. (2003). Leading the change process. Praha, Management Press, ISBN 80-7261-095-3.

[10]. Kovac, J. \& Izarikova, G. (2008). Designing line structures of production systems. Transfer innovation. No. 11, p. 243.

[11]. Linczenyi, A. \& et al. (2001). Quality management. Bratislava: STU, ISBN 80-227-1586-7.

[12]. Marsh, J. (1996). Quality tools from A-Z: Improving quality with Total Quality Management methods.AF. ISBN 80-967-022-2-X.

[13]. Masin, I. \& Vytlacil, M. (2000). New ways to higher productivity. Methods of industrial engineering. Liberec, Institute of industrial engineering.

[14]. Mateides, A. \& et al. (2006). Quality management. Bratislava: Epos, ISBN 80-805-656-4.

[15]. Panneerselvam, R. (2010). Production and operations management. Phi Learning. ISBN: 812-032767-5.

[16]. Simha, R. (2006). Introduction to basic manufacturing process and workshop technology. New Age International (P), Limited, Publishers.

[17]. Rudy, V., Malega, P., \& Kováč, J. (2012). Production management. Kosice, Technical university of Kosice.

[18]. Straka, L. (2005, October). New trends in technology system operation. In Proceedings of the 7th conference with international participation, Presov (p. 385). 